\title{
Glaciological research in Antarctica
}

\author{
Henrik Højmark Thomsen \\ and Jon Ove Hagen
}

During 1991 and 1992 the Geological Survey of Greenland (GGU) was observer on behalf of the Danish Polar Center in and preparation of a common Nordic research effort in Antarctica. The Nordic Antarctic Research Programme (NARP) involves Norway, Sweden and Finland, which are all Antarctic Treaty Consultative Partners, whereas Denmark is an observer. A natural continuation of this work was Danish participation in the Antarctic research, and a GGU glaciologist took part in the Norwegian Antarctic Research Expedition (NARE) 1992/93 arranged by the Norwegian Polar Research Institute.

The expedition started from Cape Town in South Africa, 8 December 1992 and ended at the same place on 9 March 1993. The Danish glaciological work in Antarctica took the form of stable isotope studies on blue ice areas near the Norwegian research station Troll in Dronning Maud Land, East Antarctica (Thomsen \& Hagen, in press). In addition, the GGU glaciologist took part in two Norwegian glaciological programmes, concerning the mass balance and dynamics of Jutulstraumen ice stream in Dronning Maud Land (Hagen \& Melvold, in press) and studies of iceocean interaction under the Filchner-Ronne ice shelf, West Antarctica (Orheim et al., in press). The GGU participation was financed by the Norwegian Polar Research Institute, Norwegian Research Council and Danish Natural Science Research Council.

\section{Stable isotope studies at blue ice areas}

Oxygen-18 isotope $\left(\delta^{18} \mathrm{O}\right)$ studies from deep ice-cores have demonstrated that the large ice sheets of Antarctica and Greenland are rich sources of information about climate many thousands of years back in time (e.g. Dansgaard et al., 1982; Lorius et al., 1985; Jouzel et al., 1987; Lorius et al., 1989). Comparisons of $\delta^{18} \mathrm{O}$ records from deep icecores and records measured on surface ice from the ablation zone of the Greenland ice sheet show that old ice found at depth in the central regions of the ice sheet can also be retrieved at the surface of the ice sheet margins. Here ice of different ages is found in a sequence with the oldest ice nearest to the ice edge. (Clausen \& Stauffer, 1988; Oerter \& Reeh, 1993; Reeh et al., 1987, 1991). One of these ice margin records reveals that palaeoclimatic data spanning back $c .150000$ years can be retrieved from surface ice at ice margin locations (Reeh et al., 1991). Furthermore, stable isotope studies from the Greenland ice sheet margin in the Thule area, North-West Greenland, show that the isotopic signature of the ice, in terms of mean value as well as variability, is characteristic for the site of formation of the ice and for its thermal and phase change history since the time of formation (Reeh et al., 1990).

At many locations in Antarctica blue ice is exposed at the surface. These blue ice areas have a negative mass balance and are therefore ablation zones, which implies ice flow with a net upward emergence velocity (Orheim \& Lucchitta, 1990). The blue ice areas therefore have a potential for palaeoclimatic studies, as old ice might emerge to the ice surface at these locations. $\delta^{18} \mathrm{O}$ values of scattered ice samples from blue ice areas in the Transantarctic Mountains indicate that data on the ice source areas and palaeoclimate can be retrieved from the surface ice (Faure, 1990; Grootes, 1990) in the same way as from the ablation zone of the Greenland ice sheet.

The objectives of the current study were to investigate the stable isotope signature of the Antarctic blue ice areas, to assess the source area of the emerging ice, and to evaluate the potential of these areas as source areas for palaeo-environmental studies. Surface ice samples, to be analysed for $\delta^{18} \mathrm{O}$, have been collected from two blue ice areas around Jutulsessen, Dronning Maud Land, East Antarctica.

\section{The Jutulsessen area}

The Jutulsessen mountain complex $\left(72^{\circ} \mathrm{S}, 2^{\circ} 40^{\prime} \mathrm{E}\right)$ is part of the large nunatak area running approximately parallel to and about $200 \mathrm{~km}$ inland from the ice shelf margin at the Antarctic coast (Fig. 1). The nunatak area forms a kind of barrier for the ice draining from the Antarctic plateau to the south at elevations over $3000 \mathrm{~m}$ a.s.l. Ice from the plateau drains to the lower part of the ice sheet near the coast through several glacier streams between the nunataks (Fig. 1).

A large blue ice area is developed in Sætet, the central part of Jutulsessen, and extends to the west along the west- 


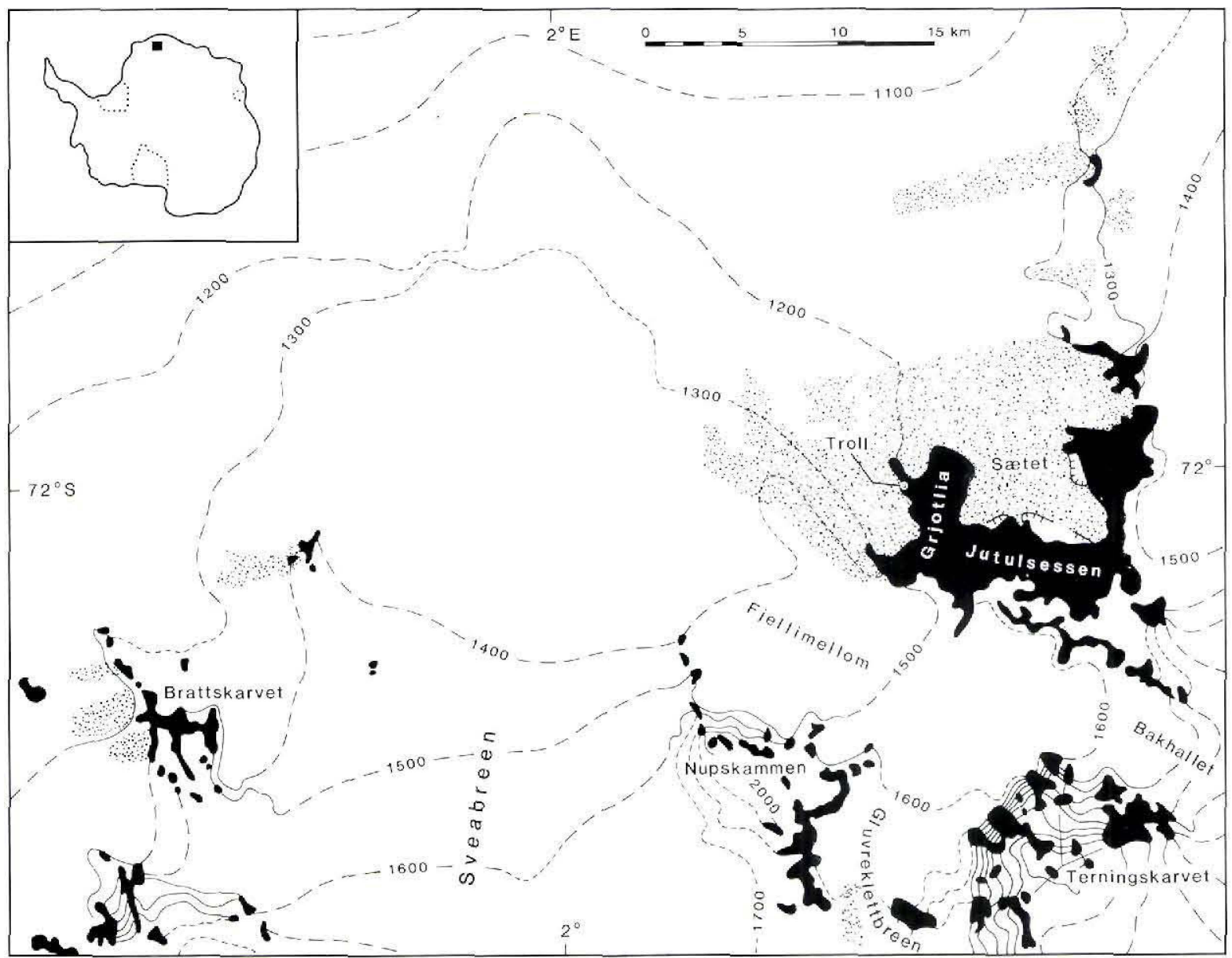

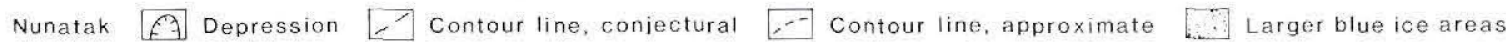

Fig. 1. Map of the Jutulsessen nunatak area. East Antarctica. Major areas of blue ice are shown. Based on Norsk Polarinstitutt (1961a, b, 199 la, b).

ern part of Grjotlia where the Norwegian research station Troll is located (Fig. 1). The surface slope of the blue ice areas indicates that the ice flows east towards Troll and south towards Sretet.

Evidence of the present ice flow to the blue ice areas is given by the general ice surface topography and ice flow structures from satellite image maps (Norsk Polarinstitut, 1991a, b, 1992). This indicates that the blue ice exposed near Troll is ice draining through Fjellimellom, partly derived from the plateau draining through Gluvreklettbreen or Bakhallet and partly from a local accumulation area at Terningskarvet (Fig. 1). The same origin is likely for the blue ice exposed at Sxtet, but there is a chance of finding ice here flowing from the plateau through Sveabreen, or from a local accumulation area at Nupskammen (Fig. 1).

\section{Ice sampling programme and preliminary results}

A total of about 650 ice and snow samples were collected from the blue ice area around Troll at Grjotlia and at Sxtet (Fig. 1) to be analysed for $\delta^{18} \mathrm{O}$. The samples were taken from the ice surface along profiles beginning at the ice margins and orientated parallel to the estimated ice flow direction. Where snow patches were present at the surface, samples were also taken from the snow. At several places along the profiles diffuse dust bands could be observed, as has been described from blue ice areas elsewhere in Antarctica (Koeberl, 1990; Cassidy et al., 1992). The dust bands are traceable for many hundreds of metres perpendicular to the ice flow direction. Furthermore, numerous frozen meltwater holes (cryoconite holes) each containing small stones or gravel material were observed on the 


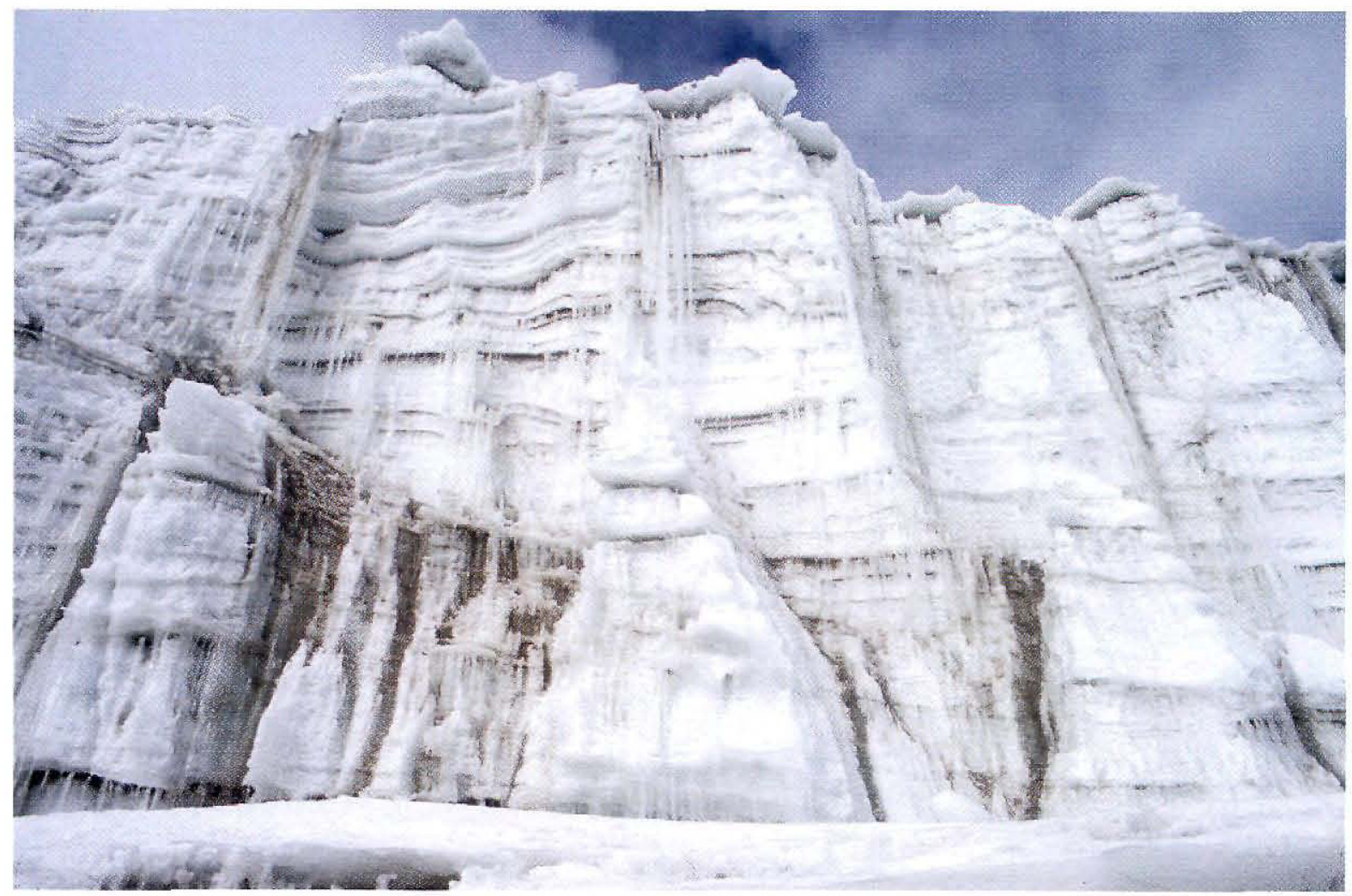

The deep frozen world of Antarctica. Vertical ice wall near the Norwegian research station Troll in Dronning Maud Land, Antarctica. Photo: Henrik Højmark Thomsen/The Norwegian Antarctic Research Expedition 1992/93.

surface. Surface structures observed along the profile lines were described and photographed to enable them to be correlated with the $\delta^{18} \mathrm{O}$ record.

The initial results are currently being assessed. It is already clear that a one kilometre long profile with a sample spacing of $4 \mathrm{~m}$ just south of Troll station (Fig. 1) shows a marked systematic $\delta^{18} \mathrm{O}$ variation from the ice margin upstream along the profile. $\delta^{18} \mathrm{O}$ values between $-43 \%$ and $-45 \%$ are typical for the outermost part of the profile near the ice margin, increasing to values between $-34 \%$ and $-36 \%$ one kilometre further upstream. Between these extreme values, three marked oscillations occur with $\delta^{18} \mathrm{O}$ changes from $6 \%$ to $12 \%$ At this preliminary stage of the work it is too early to draw conclusions, but the variations described indicate the possibility of extracting information on both ice source areas and palaeoclimate.

Acknowledgements. This paper is publication No. 130 of the Norwegian Antarctic Research Expeditions, (1992/93). The study is supported by the Norwegian Polar Research Institute, the Norwegian Research Council and the Danish Natural Science Research Council. Øyvind A. Høydal and Kjetil Melvold from the Norwegian Polar Research Institute and Jan-Gunnar Winther from the Norwegian Hydrotechnical Laboratory (NHL) are thanked for help with collection of samples. Henrik Clausen from the Department of Geophysics, Niels Bohr Institute for Astronomy, Physics and Geophysics at the University of Copenhagen is thanked for analysis of the samples.

\section{References}

Cassidy, W., Harvey, R., Schutt, J., Delisle, G. \& Yanai. K. 1992: The meteorite collection sites of Antarctica. Meteoritics 27 , 490-525.

Clausen, H. B. \& Stauffer, B. 1988: Analyses of two ice cores drilled at the ice-sheet margin in West Greenland. Ann. Glaciol. 10, 23-27.

Dansgaard, W., Clausen, H. B., Gundestrup, N., Hammer, C. U., Johnsen, S. J., Kristinsdóttir, P. M. \& Reeh, N. 1982: A new Greenland deep ice core. Science 218, 1273-1277.

Faure, G. 1990: Subice topography and the formation of supraglacial moraines, In Cassidy, W. A. \& Whillans, I. M. (ed.) Workshop on Antaretic meteorite stranding surfaces. Lunar and Planetary Institute, Terhnical Report 90-03, 32-33.

Grootes, P. M. 1990: ${ }^{18} \mathrm{O}$ results from bluc-ice areas: "old" ice at the surface? In Cassidy, W. A. \& Whillans, I. M. (ed.) Workshop on Antarctic meteorite stranding surfaces. Lunar and Planetary Institute, Technical Report 90-03, 67-69.

Hagen, J. O. \& Melvold, K. in press: Mass balance and dynamics on Jutulstraumen ice stream, Antarctica. In Orheim. O. (ed.) 
Report of the Norwegian Antarctic Research Expedition 1992/ 93. Norsk Polarinstitutt Meddr 126.

Jouzel, J., Lorius, C., Petit, J. R., Barkov, N. I., Kotlyakov, V. M. \& Petrov, V. M. 1987: Vostok ice core. A continuous isotopic temperature record over the last climatic cycle $(160,000$ years $)$. Nature 329, 403-408.

Koeberl, C. 1990: Dust bands in blue ice fields in Antarctica and their relationship to meteorites and ice. In Cassidy, W. A. \& Whillans, I. M. (ed.) Workshop on Antarctic meteorite stranding surfaces. Lunar and Planetary Institute, Technical Report 90-03, 70-74.

Lorius, C., Jouzel, J., Ritz, C., Merlivat, L., Barkov, N. I., Korotkevich, Y. S. \& Kotlyakov, V. M. 1985: A 150,000-year climatic record from Antarctica ice. Nature 316, 591-596.

Lorius, C., Raisbeck, G., Jouzel, J. \& Raynaud, D. 1989: Longterm environmental records from Antarctic ice cores. In Oeschger, H. \& Langway, Jr., C. C. (ed.) The environmental record in glaciers and ice sheets, 343-361. London: John Wiley \& Sons Ltd.

Norsk Polarinstitutt, 1961a: Jutulgryta, Fimbulheimen. Dronning Maud Land 1:250 000, sheet H5.

Norsk Polarinstitutt, 1961b: H. U. Sverdrupfjella, Fimbulheimen. Dronning Maud Land 1:250 000, sheet H6.

Norsk Polarinstitutt, 1991a: Jutulgryta, Fimbulheimen. Dronning Maud Land 1:250 000, satellite image map, sheet H5S.

Norsk Polarinstitutt, 1991b: H. U. Sverdrupfjella, Fimbulheimen. Dronning Maud Land 1:250 000, satellite image map, sheet H6S.

Norsk Polarinstitutt, 1992: Jutulsessen, Dronning Maud Land. Satellittbiletkart 1:100 000, (map with text).

Oerter, H. \& Reeh, N. 1993: $\delta^{18} \mathrm{O}$ studies on the margin of Storstrømmen, North-East Greenland. In Reeh, N. \& Oerter,
H. (ed.) Mass balance and related topics of the Greenland ice sheet. Open File Ser. Grønlands geol. Unders. 93/5, 64-67.

Orheim, O. \& Lucchitta, B. 1990: Investigating climate change by digital analysis of blue ice extent on satellite images of Antarctica. Ann. Glaciol. 14, 211-215.

Orheim, O., Østerhus, S., Melvold, K., Eiken, T., Thomsen, H. H., Winther, J. \& Bævre, H. in press: Hot water drilling near Filchner station, Ronne ice shelf. In Orheim, O. (ed.) Report of the Norwegian Antarctic Research Expedition 1992/93. Norsk Polarinstitutt Meddr 126.

Reeh, N., Thomsen, H. H. \& Clausen, H. B. 1987: The Greenland ice-sheet margin - a mine of ice for paleo-environmental studies. Palaeogeogr., Palaeoclimatol., Palaeoecol. (Global planet. Change Sect.) 58, 229-234.

Reeh, N., Thomsen, H. H., Frich, P. \& Clausen, H. B. 1990: Stable isotope studies on ice margins in the Thule area. Meddr Grønland Geosci. 22, 47-56.

Reeh, N., Oerter, H., Letréguilly, A., Miller, H. \& Hubberten, H. W. 1991: A new, detailed ice-age oxygen-18 record from the icesheet margin in central West Greenland. Palaeogeogr., Palaeoclimatol., Palaeoecol. (Global Planet. Change Sect.) 90, 373 383.

Thomsen H. H. \& Hagen, J. O. in press: A stable isotope pilot study from blue ice areas at Jutulsessen, Dronning Maud Land, Antarctica. In Orheim, O. (ed.) Report of the Norwegian Antarctic Research Expedition 1992/93. Norsk Polarinstitutt Meddr 126.

H. H. T., Geological Survey of Greenland, Copenhagen J. O. H., Norwegian Water Resources and Energy Administration, P.O. Box 5091, Majorstua, N-0301 Oslo, Norway 